\title{
Rooting and shooting behaviour of red and white pulped varieties of dragon fruit (Hylocereus undatus) in relation to indole butyric acid concentrations
}

\author{
Lalit Dhruve, V. Suchitra*, V. Sudha Vani, P. Subbaramamma and L. Saravanan \\ College of Horticulture, Dr. Y.S.R. Horticultural University, Venkataramannagudem, \\ WEST GODAVARI (A.P.) INDIA (Email : varakalasuchi3@gmail.com)
}

\begin{abstract}
The investigation was carried out to study the effect of IBA at different concentrations (2000ppm, 4000ppm, 6000ppm) on cuttings of dragon fruit cultivars viz., red pulped variety and white pulped variety to elicit their rooting and shooting parameters. The cuttings of the red pulped variety performed better than the white pulped variety. Indole butyric acid (IBA) had significant effect on rooting and shooting performance of both the varieties over control. IBA @ 6000 ppm recorded minimum number of days for sprouting (43days), maximum rooting and shooting parameters like percentage of rooted cuttings $(86.77 \%)$, number of roots $(9.87)$, length of longest root $(22.93 \mathrm{~cm})$, root fresh weight $(1.83 \mathrm{~g})$ and dry weight $(0.58 \mathrm{~g})$, length of the longest shoot $(23.93 \mathrm{~cm})$, number of new shoots per cutting (4.00), shoot fresh weight $(112.09 \mathrm{~g})$, shoot dry weight $(9.47 \mathrm{~g})$ and survival percentage $(90.26 \%)$. The least performance was observed in the cuttings of white pulped variety for almost all parameters tested except for length of shoot.
\end{abstract}

Key Words : Dragon fruit, Hylocereus undatus, Indole butryric acid, Rooting, Shooting, Cuttings

View Point Article : Dhruve, Lalit, Suchitra, V., Vani, Sudha V., Subbaramamma, P. and Saravanan, L. (2018). Rooting and shooting behaviour of red and white pulped varieties of dragon fruit (Hylocereus undatus) in relation to indole butyric acid concentrations. Internat. J. agric. Sci., 14 (1) : 229-234, DOI:10.15740/HAS/IJAS/14.1/229-234.

Article History : Received : 18.09.2017; Revised : 08.12.2017; Accepted : 20.12.2017

* Author for correspondence: 